\title{
WHERE IS THE COFFEE? COFFEE AND BRAZILIAN IDENTITY
}

\author{
Steven Topik \\ Department of History - University of California, Irvine
}

RESUMO: O Brasil e o café. O historiador costuma pensar na identificação de um com o outro. Mas na verdade, o café ocupa um lugar muito pequeno e até negativo na identidade nacional brasileira. Este artigo mostra como nem a literatura nem os estudos históricos tem priviligiado o café como formativo. Ou se enfatiza a herança colonial, a geografia, ou a mistura de raças. O campo é visto como um lugar atrasado, quase feudal que impediu a formação da identidade nacional em vez de formá-la. O café na época colonial não consta na lista de produtos importantes. No século 19, o café foi pai de escravidão e dos latifúndios. Em nosso século, o papel mais importante do café é de negar-se através da urbanização e da industrialização. Se Deus é brasileiro, Ele não toma café.

PALAVRAS-CHAVE: Brasil, Café, Identidade Nacional, História do Brasil.

ABSTRACT: Brazil and Coffee. Historians tend to identify both. But coffee occupies a small place, even a negative one, in Brazilian national identity. This article shows that neither literature nor historical studies have focused their attention on it. The focus is always on colonial heritage, geography or racial mixture. Rural areas are seen as backward with no contributions to national identity, but rather hindering it. In colonial times coffee was unimportant. In the XIX century, it engendered slavery and latifundia. In our own century, coffee's most important role was that of being denied by urbanization and industry. If God is Brazilian, he does not drink coffee.

KEYWORDS: Brazil, Coffee, National Identity, Brazilian History.

\section{Introduction}

They have a lot of coffee down in Brazil. This popular song referred to the popular association of the arabica bean and Brazil. The coffee industry long recognized that Brazil set world coffee prices. Rio 
number 7 and then Santos number 4 were the standards by which all other beans were measured. This is not surprising since 80 percent of the enormous expansion of world production in the nineteenth century was contributed by Brazil. In the extraordinary year of 1906 the country provided fully 82 percent of all the world's harvest! In most other years in the beginning of the twentieth century the number was above 60 percent.

None of this comes as a surprise to anyone who knows something about coffee. But there is one aspect of this enormous growth that is puzzling: despite coffee's unprecedented growth, neither the crop nor the fazenda de café occupied a large place in the Brazilian national identity. There are few ceremonies, statues, holidays, or folklore characters associated with coffee. Literature and music have largely abandoned the bean. Even historians, while recognizing coffee's historic importance, have slighted it. In fact, coffee is treated more as an embarrassment, a stage that had to be endured but needed to be passed through as quickly as possible.

It is striking that the canonical literature treats Rio Grande do Sul (Guimarães Rosa), Bahia cacao lands of Jorge Amado, the Northeast of Garciliano Ramos and the urban landscapes of Sao Paulo in Mario de Andrade but not the coffee fazenda ${ }^{1}$. Myriam Ellis observed: "The Valley of Paraiba is notably lacking in literary works either by authors of renown or writers of the era of coffee's growth and decline"2. Yes, Jose

\footnotetext{
${ }^{1}$ In fairness, Mario de Andrade did write about coffee in a littleknown piece: "Café" in 1942. Lamenting the Depression brought on by the fall of coffee prices he says: "Café! Café! Eu exclamo a palavra sagrada (no deserto/ Café!.... seu fruto me trazia o calor no coração/ Era o cheiro da minha paz, o gosto do meu riso/ E agora ele me nega o pão.../Que farei agora que o café nao vale mais!" I would like to thank Piers Armstrong for this reference. ${ }^{2}$ Myriam Ellis, O Café: Literatura e Historia (São Paulo: Edições Melhoramentos e USP, 1977), p. 11. Afrânio Coutinho, in An
}

de Alencar had two novels set in coffeelands, $O$ tronco do Ipê and Til, but coffee was just a setting, not an active participant. Monteiro Lobato wrote Onde verde and Julio Ribeiro A carne. Often, as in Graca Aranha's Canaã the cafezais were not prosperous places. Even so, very few major works of fiction took place in the cafézais and none treated the experience of coffee growing as formative for national identity ${ }^{3}$.

Brazilian painting also largely ignored the arabica. Basilio de Magalhaes noted that the only major piece of Brazilian painting that depicted coffee scenes was Candido Portinari's $O$ café $e^{4}$.

Although studies of Brazilian economic and political development emphasize the role of coffee, the canons of Brazilian nationality almost entirely ignore it. Many stress Brazil's colonial heritage, which had little to do with coffee. Although Brazilian nationality is seen as an import, in that the indigenous population is usually given little importance, that import was not related to arabica seedlings ${ }^{5}$. Here we have the works of Capistrano de Abreu, who noted that

Introduction to Literature in Brazil, translated by Gregory Rabassa (Nova Iorque,Columbia University, 1969) while discussing regionalism of Rio Grande do Sul, Romanticism, Modernism and pointing out that for the neo-naturalists "the land placed ahead of everything else" (p. 231) yet does not mention coffee at all.

${ }^{3}$ Graça Aranha, Canaã (Rio, F. Breguiet, 1959).

${ }^{4}$ Basilio de Magalhães, $O$ Café na história, no folclore e nas belas artes (São Paulo, Companhia Editora Nacional, 1980), p. 159. ${ }^{5} \mathrm{At}$ a few historic moments the indigenous roots were given some importance: the Romantic movement of the 1870s, the Jacobins of the 1890s, the Modernists of the 1920s, and the tropicalistas of the 1960s. But these were stylized representations of the Tupy and other indigenous peoples. Unlike Bolivia, Mexico, and Peru where the precolombian peoples have been linked intimately with cultural characteristics of the nation, in Brazil they have been invented. See Antonio Cândido, Formação da literatura brasileira (Belo Horizonte, Editora Itatiaia, 1975) especially volume 2 that links romanticism, nationalism and the image of the indigenous peoples. 
Brazil's formative history was created by the parrot, dyewood, the African slave and sugar. Gilberto Freyre pointed to the importance of sugar and the engenho de açúcar in the creation of Brazilian culture: the patriarchal "homen cordial" and racially mixed Brazilian. The importance of the rural patriarchal clan and seignorial society were the themes of Oliveira Vianna and Nestor Duarte. Joaquim Nabuco pointed to the same institutions, but blamed primarily slavery rather than latifundia. Criticizing the dominant view of the coffee elite he scoffed "when [Senator] Sr. Silveira Martins told the Senate that 'Brazil is coffee and coffee is the Negro' - not wishing of course to say slave-he defined Brazil as a plantation, a commercial etnerprise dominated by a small minority of vested intersts, in short, today's slaveholding Brazil" 6

For other seminal Brazilian thinkers, the interior forged the Brazilian identity for other seminal Brazilian thinkers, but they looked at the frontier rather than the coffee plantation. Viana Moog, distressed by the tradition of the "hollow frontier" compared the Paulista bandeirante trail-blazer with the United States settler much to the detriment of the former. Other Paulistas such as Alfredo Ellis and Sergio Buarque de Holanda lauded the bandeirante as the original true Brazilian whose initiative, individuality, continental imagination, and unique identity were formed on long treks into the continent's heartland ${ }^{7}$.

\footnotetext{
${ }^{6}$ Joaquim Nabuco, $O$ abolicionismo,( London, Kingdon,1883), p. 167; Gilberto Freyre, Casa grande e senzala (Rio: Schmidt, 1938); Nestor Duarte, A ordem privada e a organização politica nacional (São Paulo, Companhia Editora Nacional, 1939); Oliveira Vianna, Evolução do povo brasileiro (São Paulo, Companhia Editora Nacional, 1938).

${ }^{7}$ Clodomir Vianna Moog, Bandeirantes e pioneiros; paralelo entre duas culturas (Rio, Editora Globo, 1954); Alfredo Ellis, A evolução da economia paulista e suas causas (São Paulo, Com-
}

The absence of coffee as a colonial heritage is not surprising. Before the last three decades of the colonial period very little coffee was exported from Brazil. Caio Prado Junior barely deigns to discuss it in The Colonial Background of Brazil because of its relative unimportance in the colonial period ${ }^{8}$.

Another type of interior, the sertao of the Northeast, called to Euclides da Cunha and Garciliano Ramos as the truly Brazilian in the nineteenth and twentieth centuries. Again, turning their backs on $\mathrm{Eu}-$ rope and living close to the indigenous seeds of the land formed a new sort of person, a true American, though one whose animal virtues did not supersede his lack of civilization. This interior was not always seen happily, but it was seen as formative. Monteiro Lobato's caboclo Jeca Tatu, for instance, was responsible for Brazilian backwardness as much as its exceptionality. Another great nationalist, Olavo Bilac, also disdained the people of the interior ${ }^{9}$. These thinkers echoed the Argentine writer and president, Domingo Sarmiento, who counterpoised civilization and barbarism. We

panhia Editora Nacional, 1937) and $O$ Bandeirismo paulista e $O$ recuo do merediano (São Paulo, Companhia Editora Nacional, 1938); Sergio Buarque de Holanda, Visao do paraiso (SP: Companhia Editora Nacional, 1964). Buarque de Holanda reveals his ambivalence for coffee in his introduction to Thomas Davatz, Memórias de um colono no Brasil (1850) (São Paulo, Editora Itatiaia and USP, 1980) in which he notes "Era uma lavoura não somente extensiva como dissipadora-antes mineração do que agricultura (p. 16-17) and "O bandeirismo do ouro e o bandeirismo do café pertencem ambos a uma só familia (p. 33)."

${ }^{8}$ Caio Prado, Junior The Colonial Background of Modern Brazil translated by Suzette Macedo (Berkeley: University of California Press, 1967), p.154.

${ }^{9}$ Euclides da Cunha, Os sertões (Rio, Laemmert, 1902); Garciliano Ramos, Vidas secas; Monteiro Lobato, Idéias de Jeca Tatu (São Paulo, Revista do Brasil, 1920); Olavo Bilac, A Defesa Nacional; discursos (Rio, Liga de Defesa Nacional, 1917). 
have few examples of the populist attitudes of turnof-the-century Russia and United States which extolled the virtues of the rural peasant and yeoman farmer in contrast to the corruption of landlords and urban populations. In Brazil, the rural, which certainly included the coffee fazenda, was backward; it needed to be europeanized.

For this reason, none of the canons give much importance to coffee in the creation of the Brazilian identity. Even when scions of great Paulista fazendeiros families, such as Paulo Prado, wrote of the Tristeza Brasileira, the fazenda was absent. Instead, the colonial heritage and race were the main determinants. Another relative, Caio Prado Junior, concentrated much more on geography and sugar than on coffee. And when he discussed coffee, he cited its negative effects such as slavery, monoculture and latifundia. When coffee became more benign after 1889 in the "bourgeois Republic" it was because the cities came to dominate the countryside. Coffee became more beneficial because it came under urban control. Sergio Buarque de Holanda made the same argument in a brief mention of coffee in Raízes do Brasil. Afonso Celso de Figueiredo, from a Mineiro coffee family did not mention coffee in his chauvinistic tract Porque me Ufano de mеu Pais. Instead, he lyrically praised the virgin forests, the very forests coffee planters felled to make way for their cafezais. Alfredo Ellis, another child of a coffee fortune, championed Paulista exceptionalism, the locomotive that pulled twenty empty boxcars. But he pointed to the Paulista's temperate climate and white immigrant population as the roots of Paulista success rather than coffee entrepreneurship. Coffee's success was a result of geographic determinism, not a cause ${ }^{10}$.

\footnotetext{
${ }^{10}$ Alfredo Ellis, A Evolução da economia paulista e suas causas, pp. 182, 215. Caio Prado Junior, História econômica do Brasil (São Paulo, Brasiliense, 1945) and Evolução política do Brasil
}

Marxists, such as Nelson Werneck Sodre, folded together all rural "feudal" regimes and compared them unfavorably to the "modern" urban factory. He refers to "a ofensiva latifundiaria e imperialista" when discussing planters. Coffee was just a continuation of the colonial tradition; indeed, it was a stalking horse for imperialist interests that sought to hinder the development of Brazilian independence through industrialization ${ }^{11}$. In his 1946 book $O$ que se deve ler para conhecer o Brasil, an annotated bibliography, he mentions just one study of the consequences of coffee. Andre Gunder Frank, whose study of Brazil and Chile initiated the dependency approach, argued that all agriculture had similar consequences in the periphery. Coffee, just as sugar before led to a capitalism "which involved monopolization of land and other forms of capital and of labor, commerce, finance, industry and technology." Coffee led to "underdevelopment". ${ }^{12}$ Celso Furtado was kinder to coffee, which he saw as creating a "new managerial class" of Brazilian businessmen, rather than foreigners as with sugar. But it still created dependency. ${ }^{13}$

The first total history of a coffee municipio, Vassouras by Stanley Stein, saw coffee not as heroic

(São Paulo, Empresa Grafica Revista dos Tribunais, 1933); Afonso Celso de Assis Figueiredo, Porque me ufano de meu paiz-Right or Wrong, my country (Rio, Garnier, 1923). Paulo Prado, Retrato do Brasil, ensaio sobre a tristeza brasileira (São Paulo, P:L DupratMayencal, 1928); Sérgio Buarque de Holanda, Raizes do Brasil $3^{\text {rd }}$ edition (Rio, Livraria Jose Olymlpio, 1956), pp. 253, 256-257.

${ }^{11}$ Nelson Werneck Sodre, História da burguesia brasileira 3rd ed. (Rio, Ed. Civilização Brasileira, 1976), p. 207.

${ }^{12}$ Andre Gunder Frank, Capitalism and Underdevelopment in Latin America; Historical Studies of Chile and Brazil (NY, Monthly Review Press, 1969), p. 243.

${ }^{13}$ Celso Furtado, The Economic growth of Brazil translated by Ricardo W. de Aguiar and Eric Charles Drysdale (Berkeley, University of California Press, 1965), pp. 124, 173. 
or identity creating, but rather as a passing fancy. While adopting the analytical methods of the French Annale school, he viewed coffee through the traditional boom and bust cycle of Brazilian history. In Stein's story coffee was just another temporary crop like Brazilwood, sugar, gold, and rubber than experienced momentary success in the international market then collapsed when either other countries surpassed Brazilian production or when the earth wore out. Stein's story ends with decline and decadence. The legacy was "a continuation of colonial patterns of large property, Negro slavery, patriarchicalism, and accentuated class divisions" ${ }^{\prime 14}$. This is very much the story that the great Fluminense nationalist, Alberto Torres, told and anticipates dependency theory. Torres faulted coffee for damaging the national character and leaving the country open to the influence of foreign imperialism. Brad Burns noted that First Republic nationalists in general thought coffee growers "far too international in outlook" and, at the same time, too regionalist ${ }^{15}$. Other students of the Paraiba Valley also blamed coffee for the backwardness of Rio state and Minas Gerais ${ }^{16}$.

\footnotetext{
${ }^{14}$ Stanley Stein. Vassouras, a Brazilian Coffee County.( Cambridge Mass., Harvard University Press, 1958), p. 290.

${ }^{15}$ E. Bradford Burns, Nationalism in Brazil, A Historical Survey (NY, Frederick A. Praeger, 1968), p. 73; Alberto Torres, A Organização nacional (Rio, 1914).

$1^{6}$ Joao Heraldo Lima, Café e industria em Minas Gerais, 18701920. Petrópolis, Editora Vozes, 1981. Eduardo Silva, Barões e escravidão. Rio, Editora Nova Fronteira, 1984. Also see the characterizations of the Paraiba Valley in José Roberto Amaral Lapa, A economia caféeira. SP: Brasiliense, 1983 and Zelia Cardoso de Mello, O metamorfose da riqueza. São Paulo, HUCITEC, 1985. In fairness, there certainly were Fluminense and Mineiro historians who credited coffee with building up their states, for example Afonso Arinos de Melo Franco Desenvolvimento da civilização material no Brasil (Rio, 1944) and Affonso de E. Taunay, Historia do café no Brasil (Rio, Departamento Nacional do café, 1939).
}

Only the Paulista school of the late 1960s and the 1970s saw coffee as something special and formative. They stressed that in Sao Paulo free labor from Europe was used in the cafezais. Hence the legacy of inequality was quite different than for sugar or gold. Moreover, land was so plentiful that when one focused on all Brazil rather than just a municipio as did Stein, the story was one of development rather than decadence. Coffee, unlike any of the other export crops, led to industrialization. Cities and railroads sprang up in its wake. This was not the too familiar boom and bust cycle that left hollow frontiers behind it. However, coffee was still not lauded as it is in Colombia and Costa Rica. Partly, this was because the general view was that in Brazil even after the abolition of slavery a coffee oligarchy continued to rule in an autocratic way ${ }^{17}$.

Also, coffee itself was not really the subject of their studies. This is because when scholars began to focus on coffee, they were really interested in industrialization and the transition to wage labor, not coffee. Although the originators of the trend, Emilia Viotti da Costa and Warren Dean, were historians, most of their followers were economists whose research restricted itself to the origins of industrialization. Cano, Silva, Cardoso de Mello, Mello all focused on the effects in the cities. The study edited by Frederic Mauro, La preindustrialisation du Bresil, demonstrates that this perspective was a national phenomenon as the collection of regional studies all ask why their area did not industrialize like Sao Paulo ${ }^{18}$.

\footnotetext{
${ }^{17}$ See Fernando Henrique Cardoso and Enzo Faletto, Dependency and Development in Latin America translated by Marjory Mattingly Urquidi (Berkeley, University of California Press, 1979), pp. 90-92

${ }^{18}$ Emília Viotti da Costa, Da senzala a colônia. São Paulo, DIFEL, 1966. Frederic Mauro, ed. La preindustrialization du Brasil. Paris, Editions du Centre National de la Recherche Scientifique,
} 
Coffee did not form a provincial or national character so much as it fueled the leap from rural society to urban industrial society. Its greatest success was negating the society and political structure that had nurtured it.

Coffee was also taken up by students of labor relations, especially the transition to free labor. But close study of colono labor by da Costa, Dean, Holloway, and Stolcke showed that the European immigrants were generally not well treated. They had little success stamping their mark on the countryside, though they did certainly change the face of the cities of Sao Paulo and to a lesser degree Rio de Janeiro ${ }^{19}$.

More recently, several studies have pointed to the existence of small size farms in the coffee lands and the creation of a more egalitarian society in the countryside in at least some areas. Nancy Naro, Hildete Pereira de Melo, and Hebe Maria Mattos de Castro find a thriving smallholder sector in Rio de Janeiro state in the late nineteenth and early twentieth centuries. Maurico Font and Renato M. Perissinotto observe that even in Sao Paulo state, the great fazendeiros did not dominate politics. This is an extension to the provincial level of findings of Winston Fritsch and

1984. Wilson Cano, Raízes da concentração industrial em São Paulo (São Paulo, DIFEL, 1977); João Manuel Cardoso de Mello, O capitalismo tardio: contribuição à revisão crítica da formação e do desenvolvimento da economia brasileira (São Paulo, Ed. Brasiliense, 1982). Sergio Silva, Expansão cafeeira e origens da indústria no Brasil (São Paulo, Editora Alfa-Omega, 1981).

${ }^{19}$ Warren Dean, Rio Claro (Stanford, Stanford University Press, 1976) Thomas Holloway, Immigrants on the Land (Chapel Hill, University of North Carolina Press, 1980); Verena Stolcke, Coffee Planters, Workers and Wives (Cambridge, Cambridge Univ. Press, 1988).

${ }^{20}$ Renato M. Perissinotto, Classes dominantes e hegemonia na República Velha (Campinas, Editora da UNICAMP, 1994); Nancy Naro, "Customary Rightholders and Legal Claimants," The Americas XLVIII (April 1992):485-517; Hebe Maria Mattos de
Steven Topik that Paulista planters did not run the national government as they wished ${ }^{20}$. But these conclusions are far from the sort of celebrations of coffee as creating a democratic society as is sometimes suggested in Costa Rica or bringing political peace as is argued in Colombia. Rather, they suggest that the coffee oligarchy was not quite as autocratic and strong as previously thought.

The transience of coffee probably explains much of the ambivalence to it. As a predatory crop that moved inland after twenty-five to thirty years, creating often a devastated hollow frontier in its wake, coffee was a passing phenomenon. Although Brazil was large enough that it has remained the world's largest coffee exporter for over a century, coffee municipios lost their coffee prosperity rather quickly. The story of Vassouras was repeated over and over again in the Southeast. No area could identify for long with the arabica.

Given the emphasis in Brazilian history on the creation of urban culture, it is a bit surprising that almost no attention has been given to café culture. The coffeehouse was a key institution in the European countries Brazilian elites so emulated: France, Germany and to a lesser extent England. And we know that in the Southeast, at least, Brazilians drank a lot of coffee. (It seems that cacau was more popular in the

Castro, Ao sul da história (São Paulo, Brasiliense, 1987); Hildete Pereira de Melo, "O café e a economia fluminense: 1889-1920" in História econômica da Primeira República ed. by Sergio S. Silva and Tamás Szmrecsányi (São Paulo, Editora Hucitec and FAPESP, 1996), pp. 215-234; Steven Topik, The Political Economy of the Brazilian State, 1889-1930 (Austin, University of Texas Press, 1987); Winston Fritish, Winston Fritsch, External Constraints on Economic Policy (Pittsburgh, University of Pittsburgh Press, 1988). 
Northeast and mate in the South.) The New York Times reported in 1894 that:

"The whole country is perpetually in a state of semi-intoxication on coffee-men, women and children alike...At all hours of day and night, in season and out, everybody literally guzzles it. The effect is plainly apparent in trembling hands, twitching eyelids, mummy-hued skins, and a chronic state of nervous excitability worse than that produced by whisky."21

Yet there are no serious studies of coffeehouse sociability. We know that coffeehouses along the Rua do Ouvidor in Rio were a center of Bohemian life, but they have been little studied. ${ }^{22}$ Only the botequim is given much attention, and there alcohol, not coffee, reigned $^{23}$.

${ }^{21}$ New York Times, 17 July, 1894:6.2.

22 Jeffrey Needell, A Tropical Belle Epoque: Elite Culture and Society in Turn-of-the-Century Rio de Janeiro (NY, Cambridge University Press, 1987), pp. 165,189,190.

${ }^{23}$ Sidney Chalhoub, Trabalho, lar e botequim: o cotidiano dos trabalhadores no Rio de Janeiro da Belle Epoque (São Paulo, Brasiliense, 1986) and June Hahner, Poverty and Politics. The Urban Poor in Brazil, 1870-1920 (Albuquerque, University of New Mexico Press, 1986).

\section{Conclusion}

They had a lot of coffee in Brazil and it filled the pockets of the coffee barons, but it did not capture the imagination of Brazilians. In the colonial period coffee was a late-comer. It had little to do with creating patriarchal clans, latifundia, and racial mixture. In the nineteenth century coffee was blamed for rural "barons", oligarchy, and rural backwardness. In the twentieth century capital earned through selling coffee abroad brought the "modernization" sought by many urban intellectuals. But they concentrated on the urban consequences or on nostalgia of past regional societies. Coffee succeeded in extinguishing itself from the national identity. 